Виолета Стојменовић

УДК 028.5:004

Народна библиотека Бор

доИ https://doi.org/10.18485/

melissa.2016.15.2.ch3

\title{
ЕФЕКТИ ДИГИТАЛНИХ ТЕХНОЛОГИЈА НА ФОРМИРАЊЕ ЧИТАЛАЧКИХ НАВИКА
}

\section{Сажетак}

у раду се сумирају и анализирају неки од резулатата истраживања читалачких навика везаних за употребу савремених ИК уређаја и пракси читања дигиталних текстова, тј. читања са екрана, код младих, које је спроведено у периоду од септембра до децембра 2016, у борским средњим школама, путем онлајн упитника и интервјуа са фокус групама у појединим средњим школама. Главни циљ истраживања био је увид у то како млади перципирају своје читање дигиталних текстова, како се односе према уобичајеним и увреженим убеђењима да је читање са екрана заморно, да је у односу према читању штампаног материјала површније и брже (у смислу неудубљивања, прескакања већих делова текста, неразмишљања о прочитаном), да се оно што се чита са екрана теже памти јер новомедијско окружење онемогућава или фрустрира и дужину и дубину пажње неопходне за право читање тј. читање са разумевањем; како разумевају и доживљавају разлике између књиге и других штампаних материјала и дигиталног текста, односно тзв. е-књиге. Резултати и налази овог истраживања излажу се с обзиром на кључне резултате тестова и претпоставке, односно закључке савремених истраживача и тумача феномена и могућности читања у дигиталном (виртуелном) окружењу, који су били и основ за конципирање упитника и интервјуа.

Кључне речи: читање, читање са екрана, онлајн читање, читалачке навике, историја читања дигитални текст, електронска књига

\section{Предмет и методологија истраживања}

У раду се презентују неки налази изакључци истраживање чији је циљ биоувидуставове, мишљењаи искуства младих (средњошколаца) у вези са коришћењем или могућношћу коришћења савремених ИК технологија за читање. Истраживање је обављено уз помоћ онлајн упитника, који је ученицима борских средњих школа (гимназија и 
три стручне школе) прослеђен преко наставника, и интервјуа са две фокус групе (гимназија и машинско-електротехничка школа) у којима је учествовало 42 тинејџера. Упитник је имао 32 питања, од којих 7 отвореног типа (без унапред понуђених одговора). Питања су била обавезна, сем пет зависних од одговора на неко од претходних, а апликација подешена тако да се обрађују само комплетно попуњени упитници. После неколико питања о испитаниковим навикама везаним за коришћење рачунара и/или мобилног телефона уопште (врста уређаја којом се служи, број сати проведених уз њега, број профила на друштвеним мрежама и сл.) уследила су питања везана за различите аспекте читања са екрана. Већина питања тицала се поступака и ставова испитаника у вези са читањем дигиталних текстова различите врсте и дужине, од порука до тзв. електронских књига - да ли их уопште читају и како, те како објашњавају своје навике приликом читања са екрана и свој доживљај разлике између читања дигиталног и читања штампаног текста. Избор питања и формулација понуђених одговора базирани су на увиду у, иначе врло обимну, литературу (од извештаја о експериментима и тестирањима до теоријских синтеза и спекулација) о карактеристикама читања са екрана, јер се кроз њу, како ће се у прегледу приступа овом феномену видети, провлаче извесни закључци о начинима и стратегијама читања дигиталних и штампаних извора који су за рад једне јавне библиотеке са младима и те како релевантни, поготово што се на њима инсистира у више институционалних контекста и што се често преносе кроз популарне канале и на тај начин чине општепознатим и широко прихваћеним као непобитне чињенице. Овај оквир истраживања изабран је са циљем да се утврди у којој мери пракса борских средњошколаца - конкретних (не)корисника Народне библиотеке Бор, под чијим окриљем је истраживање спроведено - потврђује резултате, претпоставке и сазнања досадашњих искустава, посматрања, мерења, тестирања, анкетирања у вези са начинима читања онлајн текстова, електронских књига и сродних материјала, те са ефектима нових медија на читање уопште. Неколико питања требало је да покаже колико испитаници познају специфичне, читању намењене и за читање везане компоненте виртуелног окружења - од специфичних формата електрон- 
ских књига, преко апликација и алата за обележавање, анотирање и класификовање текстова, до платформи за међусобно повезивање читалаца, објављивање читалачких интересовања и њихово умрежавање са писцима, библиотекама, издавачима и другим актерима у процесу производње и дистрибуције материјала за читање, без обзира на то да ли их испитаници и користе или не. Све у свему, упитник је од испитаника захтевао и време и пажњу, како би се из добијених одговора извукао максимум увида у читалачке праксе и навике тинејџера које испитаници репрезентују. Стога не чуди велики проценат одустајања: само 11\% потенцијалних испитаника је упитник довршило (50 од 430). Уз помоћ Гугловог сервиса за аналитику, установљено је да је скоро половина испитаника одустала одмах, чим су видели да је реч о читању, док су остали одустајали када би на ред дошла питања везана за обрасце понашања приликом читања онлајн текстова. Добијени одговори су, даље, били основ за оквирно формулисање питања на основу којих су са споменутим фокус групама обављени полуструктурисани интервјуи. Нарочита пажња посвећена је чињеници да су анонимни онлајн одговори показали оштру поделу на оне који читање стриктно везују за штампане изворе и оне који у свакој прилици на прво место стављају дигиталне.Тако је, на пример, на питање везано за школску лектиру, 52\% испитаника одговорило да прво проба да је нађе на интернету, а 42\% - да прво проба да је нађе у штампаном облику (6\% испитаника одговорило је да лектиру никада не чита). Током двочасовних разговора, испитаници су дали детаљнији, повремено противуречан опис свог понашања и типичних поступака приликом читања са екрана, износећи своје мишљење и своје ставове у вези са неким од ставова и налаза које ћемо изнети у наставку.

\section{Приступи читању}

С обзиром на то да се читање (или појединачне компонете читања, као што су, с једне стране, брзина читања или, са друге ниво, односно степен и начин разумевања оног што се чита) може

посматрати психолошки, когнитивно, феноменолошки, неуролош- 
ки као (врло сложена) индивидуална радња и процес, али и са педагошког, односно дидактичког аспекта, као предмет подучавања и оспособљавања других да читају, било на базичном, било на неком од виших нивоа, или - као друштвени феномен - са становишта етнографије, социологије, неких теорија рецепције или студија културе, као и у контекстима које креирају специфична интересовања или (тржишни) интереси одређених група, бројност (интер)дисциплинарних приступа читању, из којих произилазе различите дефиниције и методологије, као и средства и алати проучавања и/ или подучавања читања, не изненађује. Уз то, не треба сметнути с ума да, захваљујући бројним културноисторијским факторима, читање има и своју историју, зависну и од технологија производње и дистрибуције материјала за читање тј. од медија и других (на пример, ортографских и графичких) средстава презентовања текста, њихове читљивости и доступности (не само физичке и материјалне, већ и когнитивне, која зависи од нивоа писмености, опште културе и образовних политика), колико и од система вредности и оријентација у одређеним друштвима и/или мањим заједницама, групама и сл., тј. од сврха и функција које се читању приписују и које на читање подстичу/мотивишу. ${ }^{1}$ Шта мотивише (иначе, или неку посебну групу, нарочито децу и младе) на читање, како се на ту мотивацију може утицати и како се она може развијати и усмеравати (нарочито у педагошком, тј. школском контексту) предмет је сталних истраживања и експеримената, али и доказ да се читање не може свести на једнообразано понашање. Мање или више уверљиво, понуђене су неколике су класификације мотива за читање, што (више) интринзичних, што

1 Француски истраживачи историје читања, на пример, говоре о доминацији медитативног читања у средњем веку, које је у ренесанси сменило рефлексивно и критичко, активно читање (које читаоца чини одговорним за значење и смисао (Mangel 92-93)), а које данас постепено смењује динамичко дигитално читање (Bélisle 9, 15-17). Подела на интензивно (удубљено и фокусирано) и екстензивно (брзо, површно, сваштарско) читање, чију појаву је условила хиперпродукција књига и периодике у 18-19. веку, а коју је установио Ролф Инглсинг (Price 318), до недавно се сматрала неупитном; у првом случају читање је напорна интелектуална активност у чијем фокусу је релативно мали број текстова/дела, а у другом - елеменат тежње да се стекне, освоји, потроши што више, ако не и пука разбибрига или хоби. 
(више) екстринзичних, као нпр. Гатријева и Вигфилдова. ${ }^{2}$ Мада би се исцрпност ове листе и стварна разлика између појединих мотивационих фактора могле довести у питање, ваља имати у виду да на читање могу да подстичу: радозналост, обавезе и задаци, естетски ужитак/ уживљавање, оцене и друге награде, интерперсоналана или друштвена интеракција, признање (за начитаност, ерудицију и сл.) и са њим повезано уклапање у средину у којој се читању/начитаности придаје (велика) вредност; са становишта мотивације, читање, такође, може бити изазов, улог (инвестиција) у постизање дугорочног циља, разбибрига (забава и/или бег од стварности). Од мотива(ције) зависе и читалачке стратегије, не само приступ тексту који се чита (док се чита) већ и скуп поступака који читању конкретног текста претходе и за њим следе (управљање временом и местом читања, односно атмосфером/ситуацијом у којој се чита, тражење/претраживање и избор материјала за читање, контрола пажње и концентрације, степен и смер критичко-интерпретативне обраде текста и уживљавања, комуницирање искустава/сазнања/реакција везаних за оно што се чита/прочитано). ${ }^{3}$

С обзиром на то да текстови читању нису непосредно доступни и да текстуални медији нису, како се на први поглед чини, неутрални посредници већ динамични структурални чиниоци, јасно

2 Вид. „Апендикс“ у (Guthrie et al. 330-331). Вид. и (Жиропађа 180-181).

3 Мотиви/разлози и циљеви због којих се чита јесу и један од основа класификације читања. Током истраживања читалачких навика и пракси борских средњошколаца, коришћена је подела на рекреативно читање (читање ради читања, читање из задовољства, из љубави према читању, читање у слободно време, као хоби, разбибрига или ужитак), информативно читање (читање чији је циљ да се буде у току дешавања која се сматрају битним или релевантним, да се прате јавне личности, дешавања и догађаји), сазнајно оријентисано читање (читање из радозналости, да би се нешто сазнало или да би се одређено знање проширило и употпунило, читање као део истраживања неке теме која читаоца посебно интересује, без обзира на то да ли је уз то и прагматично, практично и инструментално или не) и облигаторно читање (наметнуто читање, ради оцене, на силу, као обавеза - овде школска, као припрема за касније пословне и грађанске обавезе читања). За разлику од прве врсте читања, блиске естетском читању Розенблатове (Rosenblatt 22-47), када су текст и само читање, тј. узајамни однос („транскација“ између) текста и читаоца у средишту пажње, остале врсте читања ишле би у правцу онога што је ова ауторка назвала еферентним читањем, када је фокус на ономе што ће остати после читања, на информацији, сазнању, решењу, поступку који треба предузети. 
је да разумевање читалачких навика типичних за одређену групу, у одређеном периоду, мора да узме у обзир не само шта (у смислу конкретних садржаја, жанрова, врста), колико, зашто и када чланови те групе читају, него и из или преко, уз помоћ чега то чине, нарочито онда када, као данас, постоји више конкурентних медија за читање. Развој и диверзификација медија текста доводе, са једне стране, до појаве нових жанрова и врста текстова (твит, као посебна, дистинктивна врста текста, али и твитер прича, на пример) а са друге, и у сперзи са другим друштвено-економским, политичким и идеолошким факторима, али и са поменутом појавом нових текстуалних производа - до појаве нових читалаца, читалаца са другачијим, до тада можда и незамисливим преференцијама и интересовањима, и нових контекста (физичких и других окружења) читања.Тако су, на пример, коментари, статуси и лични ставови, односно утисци, реакције и из њих изведени типови текстова чији су аутори анонимни, тј. незванична и нестручна лица, на шта се у ери штампе наилазило ређе, у ери интернета значајно проширили читалачку публику и изменили њену структуру. Мењају се, дакле, и читалачке праксе (где се и у каквом положају чита, на пример) али и представе о томе шта читање јесте (шта је могући објекат овог глагола) а шта није. Редукционистичко схватање читања као активности чији предмет мора бити дужи (колико?) текст тј. (штампана) књига ${ }^{4}$ и оно још рестриктивније, по којем је читање приватан, чак усамљенички чин (Kar 92) (Birkerts) (Baron 113), одбацују нове и оживљене врсте или модусе читања, изазване како општим убрзањем и усложњавањем/расипањем свакодневног живота, тако и појавом нових медија (текста). ${ }^{5}$

4 Тако се, на пример, у једном истраживању читалачких навика младих (средњошколаца) у Србији, под читањем подразумева само читање књига, што води оваквим изјавама: „[О]ни који не читају, чешће [...] читају блогове“ (Крњаић, Степановић и Павловић Бабић 277).

5 Тако је, на пример, Свену Биркертсу, једна од асоцијација на читање (поред мудрости или знања) -окренутост ка унутрашњем свету (inwardness); такође, и „време осамљивања“. Искључиво повезивање читања са индивиду(ализм) ом и приватношћу не само да заборавља на бројне праксе заједничког и јавног читања (од читања детету и другим неписменим групама људи у дому, вртићу, фабрици (Mangel 119-126), кафани, библиотеци, јавном простору, 


\begin{abstract}
Колико је уврежено мишљење да је подразумевани објекат читања - књига, сведоче и одговори испитаника у овом истраживању: тек 27\% процената средњошколаца који су уопште хтели да размишљају о (свом) читању себе и доживљава као читаоце - они, мање или више редовно, читају књиге у слободно време; највећи број себе одређује као спорадичне читаоце, оне који читају ретко (48,6\%), док 24,3\% испитаника каже да не чита уопште. Поред тога, на питање за шта све користе своје мобилне и сродне уређаје, које је било отвореног типа, без унапред понуђених одговора, само $10 \%$ испитаника навело је читање. Око $30 \%$ испитаника наводи претраживање интернета (тражење информација) због школе или личних интересовања. Ипак, „сурфовање” по друштвеним мрежама, комуникација и гледање/прегледање видео клипова и других аудиовизуелних садржаја јесу доминантне активности везане за рачунар и мобилни телефон, на које, по сопственим проценама, потроше - у просеку - око 7 сати дневно јер их, наравно, упражњавају истовремено са другим активностима. Читање се, дакле, не препознаје као свакодневна, рутинска пракса. Заправо, данас је велики део читања (а за неке и читање уопште) пратилац других активности. Успутно читање разних врста порука и других текства на мобилним уређајима, у ходу, у реду, или док се седи у јавном простору или превозу, као и читање рекламних порука, информација и сличних текстова или слико-текстова са амбалажа, фасада, билборда и других јавних објеката претворених у медије, само су неки од примера за то колико су савремени друштвено-економски и медијско-технолошки услови допринели свеприсутности читања, за које се, пак, са друге стране, наводи да је у кризи. Како се у „Уводу” за један новији зборник из историје читања
\end{abstract}

преко вођеног и заједничког читања какво се и дан-данас практикује у школи, до савремених књижевних фестивала и књижевних вечери, да споменемо само најпознатије примере) него и занемарује значај културноисторијских фактора за формирање читалачких навика (од избора материјала за читање до реакција на прочитано; од „имиџа“ читаоца до функција које се читању приписују) због којих је свако читање мање или више друштвено, или, макар, друштвено уоквирено (Boyarin 4), чак и онда када води развоју слободе и независности личности. В. нпр. (Long). О савременим заједничким (породичним) ритуалним читањима пише и (Radway 275-276). 
каже: „Текст је свеприсутан и свепрожимајући, док су читаоци [или, читачи!? - readers] у покрету/мобилни, бројни и мултифункционални" (Towheed 2).

Која врста читања је заправо „у кризи”? Различити теоретичари и научници различито називају тај начин читања за који сматрају да је угрожена, ендемска пракса: дубинско или дубоко читање је, на пример, једна од чешћих одредница за такву врсту читања (Свен Биркертс, Мариен Вулф$\phi^{6}$ ( $\left.\operatorname{Kar} 55-63\right)$. Реч је, дакле, о помном или удубљеном читању, када текст читаоца, такорећи, абсорбује; о читању какво су, под називом close reading, заговарали амерички новокритичари, везујући га превасходно за књижевне и сродне, захтевне текстове; о читању као интелектуалној и херменеутичкој делатност, усмереној ка разоткривању смисла (под претпоставком да значење и смисао текста јесу скривени или се крију испод „површине” дословног). Како год га називали, и на коју год компоненту читања стављали нагласак (пажња, уживљавање, памћење, мотивација, циљеви и функције) сви „дијагностичари” лошег стања читања у савременим, медијски презасићеним, информационим друштвима „стигматизују” читање путем ИКТ (Bélisle 9). Међутим, читање као „варијабилан скуп настројености, поступања и интерпретативних стратегија" (Radway 292), као интеракција са текстом у којој учествују и емоције, афекти,

6 Дубоко читање, по М. Вулф, која је, иначе, као неуропсихолог, установила да „наш мозак није рођен за читање“, те да је способност читања резултат еволуције мозга (Wolf), обухвата: дедукцију, закључивање, аналитичко и критичко мишљење, увид, рефлексију (Wolf and Barzillai 32-33). Вид. и: (Baron 166). Нарочито је сужена представа о читању популарног носталгичара (елегичара - Гутенбергове елегије назив је његове књиге о читању у информатичком друштву) Биркертса, јер њега интересује само читање које се манифестује као потпуно удубљивање у садржај, односно „дубоко, апсорбујуће, страствено, оријентисано ка знању и мудрости“, оно које се уклапа у елитистичке концепције културе (читања), у које никако не би спадало, на пример, читање модних и других женских ревија код фризера или љубавних „викенд“ романа с киоска кришом испод школске клупе, колико год да су такве читатељке често врло страствени читаоци. Представе о читању на којима критичари читања са екрана заснивају своју критику углавном подразумевају само оно што је Елизабет Лонг означила као „ерудитно, идеационо и аналитичко читање“ (Long 182, 193). 
сензације, покрети, не може да се своди на један образац. Читаоци за које је читање начин да се прекрати („убије”) време, који се у оно што читају не улажу - а и они имају свако право да се назову читаоцима - сада на располагању имају много више могућности и много већу количину текстуалних материјала за „сурфовање” по њима, а не кроз њих (у смислу удубљивања и интензивног интелектуалног и емоционалног ангажмана). Поред тога, и рачунар, односно мобилни телефон новије генерације, као уређаји, и интернет, између осталог, служе и за читање, да не спомињемо развој уређаја који су, номинално, намењени искључиво читању (тзв. читачи електронских књига, код нас готово непознати и, захваљујући развоју и значајном појефтињењу других мобилних уређаја, мање-више непотребни). ${ }^{7}$ Штавише, могуће је приметити да се регуларно појављују:

1. нови текстуални формати, сервиси, односно алати (екстензије веб читача, софтвери, апликације и сл.) који треба да послуже томе да се процес читања као проналажења релевантних одломака олакша, те да се читање уопште учини пријатнијим и прилагодљивијим индивидуалним преференцијама, да се убрза и оснажи дигиталним верзијама „алата” које читаоци развијају већ миленијумима (чување, класификовање и повезивање текстова, подвлачење, индексирање, анотирање, маргиналије, изводи, колације итд.) - чак $82 \%$ испитаника који су попунили онлајн упитник одговорило је да никада не користи никакву алатку за маркирање и „таговање” (класификовање, сортирање, међусобно повезивање) дигиталних текстова (8\% то чини понекад, а само 10\% - редовно); 45,2\% читалаца нема навику да дигиталне текстове које чита подвлачи или да на други начин обележава делове, чак $21,4 \%$ каже да то и не уме, док су се остали читаоци определили за одговоре: само ако је текст/књига за школу (16,7\%), врло ретко (9,5\%), често (7,2\%); 36\% испитаника никада не води белешке (изводе, коментаре) везане за оно што чита, 44\% белешке води на папиру / у свесци, чак и када читају са екрана, док само 2\% испитаника

Ниједан од испитаника у овде приказаном истраживању нема ову врсту уређаја (иако скоро сви имају или рачунар/таблет (92\%) или мобилни телефон новије генерације (94\%), а значајан број (36\%) и једно и друго), при чему претежна већина никад није ни чула за нпр. Киндл или Нук. При том, готово занемарљив број испитаника (1\%) каже да би желео да такав уређај има и користи. 
познаје и користи алате за анотирање, „дописивање” онлајн и других дигиталних текстова. ${ }^{8}$

2. друштвене мреже намењене читаоцима, које, као и традиционални клубови читалаца и други облици заједничког/сарадничког читања, треба да омогуће повезивање људи сличних интересовања, размену текстова, мишљења и укуса; да читање подупру и као једно од средстава социјализације, али и широке популаризације појединих наслова, аутора, жанрова, понекад и читања уопште. Док подржавају и снаже идеју читања као друштвене, потенцијално комуникативне активности и заједничког искуства, ове платформе је чине и јавнијом, видљивијом и, стога, истраживању (и сваковрсном мониторингу) доступнијом. У правцу објављивања, тј. јавног приказивања и дељења личних преференција, реакција, утисака, интересовања и коментара иду и бројне апликације које читаоцима омогућавају да оно што подвуку и обележе учине доступним - видљивим и потенцијално утицајним, подстицајним - и другим читаоцима - када је реч о младима у Бору, ова јавност читања (још увек) није у моди. Чак 76\% испитаника никада није ни чуло за платформе као што су: GoodReads, LibraryThing, Shelfary (8\% јесте чуло, али не зна о чему је реч; 8\% јесте или је било активно на њима); само 6\% испитаника има обичај да изводе из књига које чита објављује на свом профилу, а још мањи број (2\%) објављује своје утиске и мисли о књигама. (Иначе 54\%, односно 46\% испитаника никада не бележи своје утиске и коментаре везане за оно што чита, односно не „извлачи” занимљиве или значајне делове).

Интеракција са текстом увек је и интеракција са медијем текста, због чега сва чула, а не само чуло вида и, евентуално, при гласном читању, чуло слуха, учествују у читању, утичући на формирање читалачких пракси. Тако је, на пример, разлика између читалачког доживљаја штампаног и дигиталног текста и најизразитија у до-

8 Пре нешто више од 10 година, једно истраживање је установило да традиционални облици „активног“ читања (подвлачење, анотирање и сл.) нису „мигрирали“ у виртуелно окружење (Liu 708). Међутим, то истраживање се тицало измена у читалачким навикама код људи који су се, и као читаоци, формирали пре појаве интернета. Од данашних младих корисника би се очекивао виши степен рачунарске писмености, као и шири дијапазон стратегија коришћења текстова, примерен хибридним читалачким окружењима у којима одрастају и образују се. 
мену сензо-моторичке интеракције са текстуалним медијем, који у једном случају текст чини опипљивим и опазивим у његовој целини (обиму), као физички и формално омеђен („дискретан"), а у другом - неопипљивим и видљивим само део по део (екран по екран) ${ }^{9}$, због чега је, по истраживањима, у случају читања са екрана јако тешко пратити и, још теже, поимати дуже дело као целину (Baron 152) (Mangen, Walgermo and Brønnick 66). Више од 45\% испитаника у истраживању којим смо тестирали овакве и друге закључке, што кроз одговоре на питања из упитника, што кроз разговоре у фокус групама, потврђује да избегава дуже дигиталне текстове ${ }^{10}$ (мада треба имати у виду и да је за око $10 \%$ анкетираних средњошколаца проблем само читање, независно од медија, окружења, дужине и тежине текста), те да пре или у току почетка читања проверава/процењује (у зависности од формата) дужину текста, при чему 5,4\% испитаника дигиталне текстове увек штампа, док 13,5\% - штампа дуже, а краће чита директно са екрана. Скоро 43\% испитаника није умело да наведе разлоге за то, док се разлози осталих испитаника могу подвести под: непознавање алата неопходних за активно читање (17,1\%), замор (20\%), деконцентрисаност $(51,5 \%)$ и лоше памћење (13\%).

С једне стране, штампани текст је визуелно стабилан, физички омеђен и у својој графичкој организацији непроменљив, док је визуелни, типографски облик дигиталног текста променљив (нарочито када је реч о тзв. текућим интегративним изворима, тј. веб сајтовима који се врло често, готово непрестано ажурирају, допуњују и мењају новим садржајима и новим распоредом садржаја) и тренутно прилагодљив, како врсти уређаја са којег се чита, тако и склоностима (или ћудима) појединачних читалаца. Од медија и графичке презентације текста зависи и ментална репрезентација структуре текста (Mangen, Walgermo

9 О хаптичким аспектима читања, детаљније у: (Mangen 407-410).

10 Тачније, из разговора са младима постало је јасно да се пожељним или погодним за читање сматрају краћи, издељени али, изненађујуће, не и мозаички организовани и хијерархијски неустројени текстови, они за које на први поглед није јасно да ли подразумевају одређени, задати редослед читања, када читалац сам треба да установи шта је са чим повезано, без обзира на то (или, можда, управо зато) што су се експликативни текстови на маргинама и бочне „траке“ са додатним садржајима одавно „уселили“ и у њихове званичне уџбенике. 
and Brønnick 66), а од ове, пак, начин навигације тј. кретања кроз текст(уални простор). Занемарујући чињеницу да су манипулација текстом, као увек уобличеним и посредованим одређеним медијем, и кретање кроз њега вештине које се уче и постепено аутоматизују, противници читања са екрана „натурализују” начин на који штампана књига подупире памћење и разумевање, инсистирајући на томе да се приликом читања са екрана ментална „мапа” текста не формира, што фрустрира разумевање и памћење, те да је кретање кроз простор дигиталног текста отежано јер је се локације појединих делова текста не могу меморисати (Baron 142) (Liu 702-703) (Mangen, Walgermo and Brønnick 62-63). Што се борских средњошколаца тиче, проблем памћења (независно од тога да ли се на крају опредељују да текстове штампају или остају при екрану) наводи око 13\% испитаника, мада се, када је реч о метакогницији, у њихово самопоуздање, услед склоности да се прецењују, не може имати пуно поверење, нарочито зато што су, у зависности од прецизности питања, давали противуречне одговоре. Тако су у једној фокус групи, на пример, на уопштено питање „Да ли имате утисак да слабије памтите када читате са екрана?“ углавном дали негативан одговор, који је већина преиначила после конкретнијих питања (нпр.: „Да ли можете да призовете у сећање одређено место (пасус, податак) у електронском тексту који сте прочитали?“, „Да ли вам је проблем да се сетите докле сте стигли пошто сте читање текста прекинули да бисте погледали управо пристиглу поруку/објаву?“).

Иако се причитањутекстова са одређених уређаја и у одређеним форматима симулирају покрети листања, уз визуелно (некада и аудитивно) подражавање окретања листова књиге/свеске, разлика у кинестетичкој и тактилној вредности остаје, при чему и таква „ситница" може имати пресудан утицај на читалачке навике и праксе; нарочито када се имају у виду и други материјални и чулни аспекти текстуалног медија, као што су, на пример мирис, хабање и трагови коришћења који се везују за штампане материјале и њихово трајање у времену. Не чуди стога што страствени читаоци, људи који радо и често читају, нарочито књижевна и сродна дела, преферирају књигу, тj. штампу и на тој преференцији наметљиво инсистирају (Baron 
137-141). О таквој, врло чврстој спрези праксе и објекта, читања и књиге, сведочи и неколико испитаника у оквиру овог истраживања у питању су млади (претежно женског рода) који воле да читају и који потичу из породица у којима постоји кућна библиотека и навика не само да се књиге купују него и да се о њима разговара, касније неретко подржана креативним и игроликим приступима необавезној лектири у школским литерарним или читалачким секцијама. ${ }^{11}$ Иначе, сви испитаници који су навели да воле да читају, да читање упражњавају у слободно време, за читање из задовољства (рекреативно читање) бирају, тј. преферирају штампану публикацију, коју могу да поседују и да је физички размењују и обележавају, остављајући по њој трагове свог коришћења. Чак 30,4\% испитаника који су у оквиру онлајн упитника одговорили да не (воле да) читају електронске књиге, навело је управо недостатак мириса и додира књиге и звука листања као кључни и, из истраживања већ добро познат разлог за то (Baron 214).

Када је, пак, реч о истраживачком читању, јавила се значајна разлика између испитаника који похађају гимназију и оних који су ученици стручне, и то електро-машинске школе: за разлику од ових других, који за истраживање теме од интереса преферирају екран и прво бирају онлајн изворе, гимназијалци су подељеног мишљења. Половина испитаника користи искључиво штампане изворе и за ову врсту читања, док друга половина преферира онлајн изворе, мада и међу њима има оних који избор медија везују за степен интересовања: што их тема више интересује, то је већа вероватноћа да ће прво потражити и прочитати штампани извор/штампану верзију извора.

Сумарно, само 20\% испитаника је одговорило да чита књиге у неком електронском формату (неки од њих чак и у школи, кришом, за време досадних часова); ипак, свега 4\% то чини често; што се осталих тиче: 22\% испитаника пристаје на електронску књигу само ако не може да дође до штампане верзије, 24\% - врло ретко, а 30\% - никако. Више

11 Испитанице о којима је реч су, при том, изненађујуће свесне (или, можда, подучене) да је у њиховом случају читање (штампаних књига) део изабраног „животног стила“, те да им размењивање књига и разговор о њима помажу да изграде „осећај припадности групи“ (Ј. С. (16 год.)), а самим тим и један од елемената разликовања од других (група), не само од оних који не (воле да) читају, већ и од оних који на читање гледају на другачији начин. 
од $17 \%$ испитаника из ове последње групе не уме да објасни због чега не жели или не може да чита електронске књиге; остали наводе добро познате разлоге - замор и одсуство концентрације/лоше памћење.

Најраспрострањенија и најфреквентнија врста/сврха читања са неког од савремених ИК уређаја могла би се, ипак, подвести под информативно читање - читање да би се било у току са актуелним дешавањима, праћење вести и новости. Ово читање, које се, како је разговор са младима показао, манифестује као део сурфовања по приватним и институционалним или корпоративним профилима на друштвеним мрежама, процес читања приближава, а често и изједначава са (пре)гледањем; гледају се наслови и други визуелно истакнути елементи текса. Јасно је да ниво когнитивне обраде уочених слико-речи, у највећем броју случајева, не може да се назове читањем, сем ако се ово на сведе на пуко препознавање слова и речи. Поред тога, разговор је показао да прва асоцијација средњошколаца на појам вести нису обавештења везана за догађаје у политици, култури, друштву, економији, већ приватни живот познаника и јавних личности, односно таблоидна, сензационалистичка обавештења. Заправо, 50\% испитаника уопште не чита, тј. не прати неки дневни лист, новине, часопис, а 26\% њих прати само онлајн издања тј. сајтове издавача новина или часописа. Око 30\% испитаника прати неки блог; друштвене мреже су, бар када је о младима реч, блогове брзо бациле у запећак, тако да, на пример, само један испитаник наводи да пише и уређује свој блог. Притом, од испитаника који читају новине, часописе, блогове и друге серијске публикације, онлајн и/или штампане, 47,1\% испитаника каже да само текстове чији им је почетак интересантан заиста и прочита до краја; 26,5\% испитаника никада не чита целе текстове, $11,8 \%$ то чини ретко, а 14,7\% каже да објаве оних које прати увек прочита у целини, без прескакања делова. Да ли је све наведено, ипак, доказ да је читање (из) књига само по себи „дубље” и „продорније” него читање са екрана?

Читање увек, независно од медија, може бити површно, брзо, чак и компулзивно (када се нешто чита просто зато што је ту, на дохват руку и очију, зато што се појавило и наметнуло пажњи ван контроле воље) и, наравно, принудно, када је наметнуто као школска, 
пословна или грађанска обавеза. Ако имамо у виду да је читање некада било привилегија малог или релативно малог броја људи, који су своје читалачке способности и праксе развијали у знатно другачијим околностима, док су данас готово сви, хтели-не хтели, и читаоци, при чему је и корпус разлога због којих се чита и циљева који се читањем желе постићи поприлично нарастао, онда је ламентирање над немогућношћу да се „дубоко” читање одржи као пожељан или, чак, идеалан облик рецепције, коришћења или конзумације текстова узалудно. Заправо, превласт корисничког (или прагматично-инструменталног) и конзументског типа односа према тексту над рецепцијским и јесте једна од битнијих карактеристика читања данас. Охрабривање и подстицање како потрошачког и рекреативног, тако и фановског, али и библиотерапијског односа према читању, односно текстовима, чини се да су основне тржишне и маркетиншке стратегије одржавања интересовања за књигу и читање.

\section{Расејани читалац}

Истраживања и дебате везане за модусе читања текстова са екрана непрестано прате развој рачунарских технологија (Baron 12, 168ff), (Mangen, Walgermo and Brønnick 161-162); огромна распрострањеност како рачунара и мобилних телефона, тако и интернета, које су довеле не само до неконтролисане пролиферације нових текстова различитог формата већ и до својеврсног култа дигитализације и дигиталног приређивања већ постојећих, само их је интензивирала. При томе се, врло често, одређени образац читања узима као доминантан, ако не и искључив, када је о читању са екрана реч, без разматрања мноштвености (могућих) читалачких пракси и стратегија, које зависе како од мотива, циљева и функција читања у конкретним, индивидуалним случајевима, тако и од традиционалних читалачких вештина, (не)наслеђених и (не)научених кроз школовање и образовање, у које спадају и, за данашњег читаоца преважна вештина контролисања и усмеравања пажње и вољна концентрација, али и од знања и вештина везаних за коришћење одређених рачунар- 
ских програма или апликација и виртуалних „читаоница”, тј. сервиса који су део дигиталних библиотека, архива, репозиторијума и других „агрегатора" и претраживача текстова на интернету. Разумевање и/ или истраживање рачунарски асистираног или екранског читања требало би, ипак, да подразумева и сазнања у вези са (не)коришћењем бројних алата интегрисаних у саме дигиталне текстове или њихово виртуално окружење.

С једне стране се, дакле, претпоставља да свакодневно и скоро целодневно „бивање” на интернету (или, уже, на друштвеним мрежама, од којих се, нарочито када је реч о младима, не одваја ни када се ради нешто друго, у складу са „идеалом” сталне умрежености и непрекидне комуникације ${ }^{12}$ ) и коришћења рачунара као медија свих медија, фаворизује одређене начине читања, чинећи их све искључивијим, тако да се они практикују као начини читања уопште, независно од медија и/или формата. Чак и када је реч само о читању са екрана (а не о поређењу читалачких пракси везаних за штампани материјал и екран), најчешће се не испитује разлика између читања које се одвија у онлајн окружењу (које је све флуидније и све динамичније, било зато што се нека врста покрета и/или промене и анимације интегрише у све, па и у чисто текстуалне садржаје, најчешће мозаички или калеидоскопски презентоване и испреплетане са другим аудио-визуелним садржајима, било због све већег броја самоискачућих рекламних и других порука) и читања дигиталних/дигитализованих текстова у посебним, самосталним, офлајн форматима, који омогућавају релативну изолованост или иступање из бујице информација, порука, бескрајних ланаца хипервеза и других стимуланса расејавања интересовања, тј. „дистрактора” пажње. Нова „дивљина” - „дивљина информација" (Sosnoski 165) - намеће извесне, наводно регресивне, тј. „примитивне” когнитивне стратегије: велику, рефлексну брзину измене и непрестану прилагодљивост фокуса опажања и пажње (Wolf and Barzillai 35) (Kar 77, 100ff). Дугорочан и далекосежан утицај

12 Већ је споменуто да млади испитаници процењују да - просечно - проводе по 7 сати дневно на интернету. Друштвене мреже се појављују као прва сврха коришћења рачунара и мобилних уређаја у више од $80 \%$ одговора. Број профила испитаника креће се у распону од три до пет, мада немали број (28\%) наводи седам, односно (20\%) - десет личних профила. 
преурањеног и неумереног коришћења интернета, као примарног извора сазнања, информација, забаве, на читалачке навике, проистиче из његовог трајног утицаја на "пластичан" тј. променљив и прилагодљив мозак - чији степен и брзину прилагођавања, тј. реорганизације неки аутори, попут Кара, представљају на врло драматичан начин - који се навикава на дељење пажње на више задатака и истовремених активности, на расејаност, нестрпљивост, брзоплетост, површно пабирчење неповезаних информација, лако западање у досаду, док се, услед некоришћења, мождани склопови који одржавају „старе интелектуалне функције” (пажљиво и дуго читање, промишљање прочитаног, поступно извођење закључака, синтетизовање идеја, појмова и знања) - распадају (Kar, 95). По тој тези, интернет „укида [и саму] жељу за усредсређеним читањем” (Gordić, 177) и производи расејаног читаоца, јер онемогућава већ споменуто „дубоко” или „дубинско”, интелектуално и емоционално ангажовано (Miall and Dobson), док подстиче (пре)брзо, летимично, површно, „забушантско”, „тумарајуће” или „шпартајуће” (reading on the prowl (Baron 22-23, 161, 229)), читање на прескок, „комадајуће” читање, које занемарује текст као целину и само „штрпка” или „скида кајмак" (skim) деконтекстуализованих информација. О такозваном F обрасцу читања, којим се скреће пажња и на доминантну путању читања онлајн текстова и на његову брзину (fast) све се чешће говори (Kar 116-117). Подршку за своје ставове, критичари читања са екрана налазе у резултатима мерења и тестова у оквиру експерименталне когнитивне психологије, неурологије и сличних дисциплина, које се у својим истраживањима служе савременим апаратима за посматрање и праћење можданих функција и активности. Оне, наводно, нуде егзактне податке о разликама између читања (разумевања, памћења) штампаног и дигиталног текста. ${ }^{13}$ Међутим, резултати научних истраживања нису, сами по себи, довољан оквир за разумевање феномена читања јер су друштвене конвенције, предрасуде, мњења, добијеним коришћењем магнетне резонанце и других уређаја за праћење и анализу рада мозга, „прескачу“ критике на рачун рада самих уређаја и тумачења података добијених њиховим коришћењем (Hejls, Kako čitamo 272-274). 
мода и навике за формирање читалачких стратегија врло важне, независно од тога шта науке кажу о квалитету и, уопште, природи читања текста у одређеном медију. Стога, пракса понекад противуречи налазима експеримената или их чини беспредметним. ${ }^{14}$ Поред тога, део тих истраживања прати промене у карактеристикама читања текстова (и последично, степена њиховог разумевања, памћења и сл.) које се одвијају са појавом и даљим развојем рачунара и програма ${ }^{15}$, док су за истраживање о којем је у овом раду реч од превасходне важности навике и стратегије које се, тако рећи од почетка, формирају у хибридном окружењу. Данашњи млади (тинејџери, адолесценти) одрастају у свету инстант информација; за њих преобиље материјала за читање јесте саморазумљива датост а не шокантна и фрустрирајућа новина; дигиталне технологије, у већини случајева, од почетка учествују у изграђивању њихових читалачких пракси и навика, колико и упозорења, ограничења, оптужбе или казне везане за њихово коришћење. Њихови ставови и праксе стога се, ипак, разликују од ставова и пракси већине старијих генерација.

14 Уврежено је, на пример, мишљење да је читање са екрана заморније него читање штампаног текста, да фрустира и пажњу и памћење и разумевање, које се, иначе, мери способношћу одређивања теме и извођења закључака (Hejls, Kako čitamo 257) и, у новије време, концептуализује као читалачка писменост (Павловић Бабић 150-166). Тестирања разумевања и памћења најчешће показују да је читање хипертекстуалне (екранске) верзије текста спорије у односу на читање штампане верзије истог текста и да су читаоци у првом случају мање запамтили (Kar, 109-111) (Mangen, Walgermo and Brønnick). Међутим, по једном истраживању читање са савремених екрана уопште није заморније, јер се око понаша скоро исто, када прати текст на екрану и на папиру. Стога аутори овог истраживања доказују да су преферирање штампаног материјала и утисак да је он читљивији субјективни јер су, испитујући степен разумевања прочитаног и мерећи неуролошке и активности ока, установили да не постоји разлика у когнитивном напору (Kretzschmar, Pleimling and Hosemann). С друге стране, резултати експеримента обављеног уз помоћ јако кратких текстова (176-266 речи) тешко да ишта заиста потврђују или оповргавају. Интересантно је, свакако, да управо млади, процентуално више него старији, сматрају да је штампани материјал пријатнији за читање и читљивији, у смислу лакоће и брзине разумевања. И испитаници у оквиру овог истраживања то тврде.

15 Такво је, на пример, доста утицајно и често навођено истраживање Зиминг Лиуа (Liu), по којем нови начини читања укључују: прегледање, очитавање тј. својеврсно скенирање текста, уочавање кључних речи, нелинеарно и једнократно читање (у смислу да се читаоци више не враћају на текстове које су једном прочитали, у целини или делимично, или скенирали). 
Насупрот забринутој критици савремених тенденција да се читање претвори у део претраживања, скроловања, лоцирања кључних речи и информација или да, чак, постане синоним за проналажење информација (Baron 39), стоји својеврстан култ хипертекста као механизма ослобађања читалаца од стега линеарности и унапред задатих путања читања штампаног текста, који се јавио у другој половини деведесетих година двадесетог века. ${ }^{16}$ Неки теоретичари су у хипертексту видели реализацију постструктуралистички схваћене (флексибилне, отворене) текстуалности, бартовског текста-мреже (Landow 53-68). По њима, хипертекст „ради” оно што текст иначе подразумева: успоставља везе са (потенцијално свим) текстовима, по принципу контигвитета, асоцијативности, итеративности језичких знакова, услед промењивости контекста и његовог повратног утицаја на смисао, значења и употребе текста. Занемарујући за тренутак чињеницу да овакви аутори обично на уму имају хипертекст у ужем смислу (текст програмиран и кодиран тако да садржи везе ка спољашњим - експликативним, асоцијативним, евалуационим, прерађеним и другим релевантним, смислено повезаним садржајима и интегрисане додатне садржаје који се активирају по вољи и избору читалаца) и чињеницу да је сваки онлајн текст ауто-

Уп. нпр.: „корисници [хипертекста] потпуно су слободни да следе везе (линкове) докле год им је воља“ (Ландоу у: (Miall and Dobson)); њихово „оснаживање“ (empowerment) резултат је учешћа у конструкцији (привременог) текста који ће читати од вишеструко организованих текстуалних јединица (Landow 51). Неки чак сматрају да структура разгранатих веза и чворишта симулира асоцијативне и мрежне процесе који се одвијају у људском уму, те да хипертекст заправо подржава и подражава мишљење (Ландоу и Дилејни у (Kar 108-109)). Реч је, пре, о ономе што је Кетрин Хејлс означила као разлику у когнитивним стиловима (Hayles, Hyper and Deep Attention 187), мада се она не мора, како то ова ауторка чини, посматрати само као генерацијска разлика: с једне стране је мишљење које нагиње конструисању и праћењу поступног, континуираног, кумулативног, усредсређеног, кохерентног, логичног и логички структурисаног „тока“, а са друге - мишљење склоно асоцијативним скоковима и прескоцима, паралелзму, јукстапозицији, дигресији, расипању и разгранатости, па и својеврсној модуларности аргумената, закључака, идеја. Сматра се да књига даје подршку, развија и привилегује, „натурализује“ овај први, а хипертекст - овај други начин мишљења (и читања). Стога не чуди то што је дезоријентација (у тексту, у кретању у између текстова), као чест пратилац или резултат коришћења интернета, за једне извор фрустрације, а за друге - задовољства у склапању и повезивању, тј. ужитка (Miall and Dobson) (Landow 144-150). 
матски хипертекст (не само зато што је кодиран, већ и зато што је сваки елеменат текста потенцијално и кључна реч за претраживање целокупне мреже, дакле, веза) не може се, ипак, занемарити разлика између „хипертекста” који се ствара током читања, активирањем читаочевих индивидуалних предзнања, асоцијација, интересовања, која управљају интра- и интертекстуалним везама које се чином читања креирају и унапред програмираног хипертекста који је резултат интенционалне и неинтенционалне сарадње многих хетерогених знања (људских и машинских ${ }^{17}$ ). Поред тога, аутоматско, тј. компулзивно и незналачко праћење задатог следа погодака и веза ка другим садржајима, на шта ови аутори, искусни и натпросечно образовани читаоци, нису рачуналаи - а већина испитаника у овом истраживању потврдила је да углавном следи аутоматски генерисан низ погодака, без „читања” адресе и покушаја закључивања о релевантности извора на основу сажетака и исечака - као и препуштање контроле над сопственим временом и пажњом искачућим порукама, тешко да се могу подвести под појам слободе. Другим речима, инсистирање на томе да је читалац хипертекста слободнији према тексту (и аутору) у односу на читаоца штампаног (или рукописног) текста и, нешто касније, инсистирање на суштински новој природи интерактивности на релацији аутор (писац) - (уређај -) читалац и директном учешћу читаоца у креирању и мењању садржаја, што је омогућио развој технологија интернета и појава тзв. Веб 2.0 ${ }^{18}$, заснива се на вредновању видљивости читаочевих доживљаја и активности (од емоционалних и естетских реакција, преко тумачења и коментарисања, до дијалога/полемике са текстом и његовим ауторем и директног уплитања у процес стварања/писања) и својеврсном

17 Кетрин Хејлс говори о „киборг читалачким праксама“ (Hayles, Print is Flat 68, 85) јер је у основи сваког дигиталног текста алгоритам који уређај мора да „прочита“ да би се текст појавио на екрану читаоца. У том смислу, читање са екрана је увек „сарадничко“: уређај и човек читају заједно, сваки свој слој или део дигиталног текста. Арсет је онај дубински, програмски текст назвао текстоном, а онај површински, који читалац опажа и чита - скриптоном (Uspenski 87-89). С обзиром на то, дигитални текст је, заправо, виртуалан (Landow 37), и као такав, врста слике (Hayles, Print is Flat 70) (Landow 37, 193). О „новом“ тј. „читању 2.0“ реч је у (Софронијевић 196). 
презиру према читалачким реакцијама и активностима које остају на нивоу унутрашњег доживљаја, интимне, приватне или разменљиве само унутар уских кругова, најчешће без трајног трага, незаписане, ефемерне, због чега их неки, чак, третирају као пасивну рецепцију.

Даље, иако је тачно да доминантан начин онлајн читања укључује слободно комадање текста, непоштовање задатих секвенци и целина, конструисање индивидуалних путања кретања кроз текст и између текстова, није тешко приметити да се читаочева наводна контрола над ланцима, петљама или колима текстуалних јединица често преокреће у компулзивно и/или конфузно праћење нагона за откривањем. На питање везано за учесталост активирања линкова у онлајн текстовима које читају или у њиховом окружењу, испитаници су одговорили на следећи начин: 10\% каже да активира само линкове који воде из самог текста, за које су сигурни да имају директне везе са оним што читају; $16 \%$ често насумице „кликће”, док исто толико то никада не чини, игнорише везе; 28\% отвори везу у новом језичку / прозору за касније читање (мада чак $38 \%$ испитаника признаје да не успева да прочита све што изабере / припреми / преузме за накнадно читање, док само 16\% испитаника, по сопственој процени, то редовно успева); 30\% испитаника ретко активира линкове, а када то чини - чини не на основу процене значаја везе већ због интригантности и примамљивости линка. Само 20\% испитаника у овом истраживању одговорило је да им се никада не дешава да се „изгубе” следећи линкове и искачуће везе; 18\% каже да је то честа појава, а највећи број - 62\% - потврђује могућност конфузије, мада не признаје да се то дешава баш често. 56\% испитаника потврдило је тзв. „мултитаскинг” - често им је активирано више прозора / апликација истовремено, тако да „скачу” са садржаја на садржај; само 10\% испитаника каже да никада не чита / гледа више садржаја наизменице. Само три испитанице су рекле да се повремено дисконектују да би нешто на миру прочитале; остали то не чине, иако скоро сви кажу да непрестани проток порука јесте сметња и да деконцентрише.

Колаж или бриколаж, мозаик, слагалица, пачворк и други начини спајања хетерогених исечака или, чак, отпадака јесу адекватне метафоре онлајн читалачких пракси али су њихови резултати, 
противно очекивањима теоретичара одушевљених (очигледнијом, видљивом иако неопипљивом) могућношћу реорганизације (и „деауторизације") текстова у тополошке, логичке или асоцијативне обрасце (Sosnoski 172) који су релевантни за читаочеве/корисникове тренутне и личне потребе, упитни, показало се, када је реч о квалитету или етици.

На крају, чињеница да се штампани текстови (али не и у новинама, магазинима, ревијама, на плакатим, у енциклопедијама) углавном читају линеарно, јер су линеарно изложени, не значи да је штампани текст по природи линеаран и да су његове секвенце апсолутно непомичне и непроменљиве, као и хијерархије делова који га сачињавају. Другојачијост читања дигиталних текстова не може се објашњавати само на основу тога што је низ читалачких стратегија у хипертекст већ интегрисан, па текст садржи и програме/алгоритме за сопствену обраду и прераду (аутоматски резиме, лоцирање тражене речи/фразе итд.); читање зависи и од медија и од конкретног формата текста, али и од специфичних физичких и других контекста и окружења у којима се одвија.

Испрекиданост, фрагментарност и нелинеарност, као кључне одлике (читања) дигиталних текстова, очито се у различитим приступима вреднују на дијаметрално супротан начин. Исти је случај и када је реч о развоју графичког интерфејса, без којег је приступ дигиталном тексту немогућ, и о тенденцији да се сваки текст угнезди у масу додатних мултимедијалних садржаја, линкова, менија различите намене (да се „обогати”), због чега је читалац приморан да непрестано бира и одлучује своју путању читања/коришћења, што интеракцију са дигиталним текстом чини потенцијално чулно стимулативнијом, али и заморнијом. Мултимедијалност и мултилинеарност текста једни величају, а други, без обзира на то што и сами објављују текстове у истом том преоптерећеном и преоптерећујућем окружењу - критикују. Ако је развој технологије уклонио некадашњи кључни узрок бржег замора приликом читања са екрана или, чак, немогућности да се са екрана чита ишта дуже, а то је сам екран ниске резолуције, са лошим позадинским осветљењем и контрастом, он је, истовремено, поспешио свеприсутност оних других извора замора: преобиље визуелних и 
когнитивних стимуланса (боје, анимација, могућност пуне активације већег броја програма (и прозора) истовремено, велики број иконица, „дугмади”, бочних трака, самоискачућих прозора итд.) (Kar,105-107). ${ }^{19}$ Замор и јесте разлог који наводи највећи број испитаника који су одговорили да не читају књиге у електронском формату $(34,8 \%)$.

Да ли је нужност „монтажног” читања извор фрустрације или својеврсног ужитка у слагању, склапању и повезивању није питање на које је могуће дати категоричан одговор. ${ }^{20}$ Данашњем читаоцу је изузетно разнолик садржаја готово непрестано на дохват руке, при чему сама та доступност и разноликост (без обзира на то да ли се оне реално искоришћују или не) као и могућност приступа садржајима који одговарају тренутним (да ли нужно и краткорочним, ћудљивим, спонтаним) интересовањима као да представља вредност по себи. Да ли то показује да су честе и нагле промене интересовања, препуштање ћудима и случајним стимулансима, изненадним асоцијацијама, чест скуп карактеристика савременог читаоца или да је интернет идеалан извор онда када је избор материјала за читање завистан од тренутног расположења и интересовања, од диктата тренутка?

\section{Уместо закључка}

Анализом одговора на питања из онлајн упитника и кроз разговоре у оквиру фокус група, дошли смо до закључка да код младихиспитаника (борских средњошколоца) постоји склоност да читање са екра-

О когнитивном преоптерећењу приликом читања онлајн и мултимедијалних текстова, као о преоптерећењу тзв. радне или краткорочне меморије читаоца (што онемогућава трансфер сазнања, информација, утисака у дугорочно памћење) говоре и: (Baron 173) (Mangen, Walgermo and Brønnick 61).

Флусер сматра да је током друге половине 20. века дошло до превласти читања као прикупљања а не разоткривања смисла, читања које је као склапање мозаика или слагалице, тј. кибернетичког над херменеутичким читањем. То „монтажно“ или, како га он назива, „калкулаторно“ читање (Flusser 84), међутим, претходи појави интернета и свеприсутности ИК геџета, мада јесте условљено развојем кибернетике и кибернетичких научних модела и процедура. У основи овог прелаза са (раз)откривања на синтетизовање или амалгманисање јесте имплицитно уверење да смисао не претходи читању; смисао је производ или резултат чина читања (Flusser 85). 
на сматрају видом или делом забаве (током „сурфовања”, што је њихова кључна реч када говоре о коришћењу интернета) или истраживања у смислу прикупљања података и информација, ређе истраживања као распитивања (у циљу решавања одређеног проблема). Превасходно је реч о еферентном, а врло ретко о естетском читању (Розенблат), тј. о употреби нових технологија за информативно (практично-сазнајно оријентисано, прагматично, инструментално) читање, ретко праћено промишљеном, а не насумичном селекцијом материјала за читање и стратегија читања. Међутим, за младе је интерес(овање) кључан мотивациони фактор: како тврде, када их нешто заинтересује или им је заиста потребно, читају без обзира на медиј, формат, „дистракције”, и - читају до краја. С друге стране, услед уочене склоности ка лошем процењивању својих способности контролисања пажње, селекције, навигације и усредсређивања, млади би, свакако, имали велику корист од наставе која би се мање ослањала на предавања а више на заједничка, тј. вођена читања различитих извора наставних тема и садржаја, ${ }^{21}$ чиме би се поспешио и жељени развој дубинског и критичког читања, али и још пожељнији трансфер вештина и читалачких стратегија (Wolf and Barzillai 36), стечених на примеру „мрских”, тј. облигаторних текстова и докумената. Штавише, на тај би се начин унапредили њихово познавање и разумевање разних врста текстова као облика изражавања, означавања и комуницирања, са којима се, у зависности од медија, структуре, композиције, стила и других конституената успостављају и треба да успостављају различити односи, и спрега̂ текстова са другим врстама садржаја, али и са контекстима у којима се појављују и мотивима, циљевима и функцијама који њихову појаву провоцирају.

\section{Литература}

Жиропађа, Љубомир. „Колико се читало некад и колико се чита данас.” Теоријски и примењени аспекти психологије читања. Београд: Институт за психологију : Академска мисао, 2013. 178-195.

21 Критику наставе оријентисане на предавања (монолошки метод) и репродуковање наставних садржаја, у контексту развоја тзв. читалачке писмености, износи (Павловић Бабић 166-168). 
Крњаић, Зора, Драгица Павловић Бабић и Ивана Степановић. „Читалачке навике средњошколаца у Србији." Зборник Института за педагошка истраживања 43.2 (2011): 266-282.

Павловић Бабић, Драгица. „Процена вештине читања у школском контексту.“ Теоријски и примењени аспекти психологије читања. Београд: Институт за психологију : Академска мисао, 2013. 145-177.

Софронијевић, Адам. „Читање 2.0 : зашто би библиотекари требало да буду заинтересовани?" Хоризонти светског и европског библиотекарства у дигиталном добу : зборник радова са међународне научне конференције, Београд, 27-28. октобар 2011. Ур. Весна Црногорац / Весна Ињац. Београд: Библиотекарско друштво Србије, 2012. 189-202.

Baron, Naomi S. Words Onscreen: The Fate of Reading in a Digital World. Oxford et al.: OUP, 2015.

Bélisle, Claire. "Introduction." Lire dans un monde numérique. Ed. Claire Bélisle. Lyon: Presses de l'Enssib, 2011. 9-48.

Birkerts, Sven. "The Time of Reading: A meditation on the fate of books in an impatient age: (A lecture given May 1, 1996 at the New York Public Library)." Summer 1996. Boston Review. 17 October 2016 <http://bostonreview.net/archives/BR21.3/ Birkerts.html>.

Boyarin, Jonathan. "Introduction." The Ethnography of Reading. Berkeley, Los Angeles, Oxford: University of California Press, 1993. 1-9.

Flusser, Vilém. Does Writing Have a Future? Trans. Nancy Ann Roth. Minneapolis: University of Minnesota Press, 2011.

Gordić-Petković, Vladislava. „Novi mediji i pismenost - poetika ekrana i nove forme čitanja." Kultura 133 (2011): 176-183.

Guthrie, John T. et al. "Growth of Literacy Engagement: Changes in Motivations and Strategies during Concept-Oriented Reading Instruction." Reading Research Quarterly 31.3 (1996): 306-332.

Hayles, Katherine N. "Hyper and Deep Attention: The Generational Divide in Cognitive Modes." Profession (2007): 187-199.

- "Print is Flat, Code is Deep: The Importance of Media/Specific Analysis." Poetics Today 25.1 (2004): 67-90.

Hejls, Ketrin N. „Kako čitamo: blisko, hiper, mašinski.” Strategije čitanja. Ur. Mirjana Stošić. Beograd: Centar za medije i komunikacije. Fakultet za medije i komunikacije, 2014. 257-286.

Kar, Nikolas. Plitko: kako internet menja način na koji mislimo, čitamo i pamtimo. Smederevo: Heliks, 2013.

Kretzschmar, Franziska, et al. "Subjective Impressions Do Not Mirror Online Reading Effort: Concurrent EEG-Eyetracking Evidence from the Reading of Books and Digital Media." PLoS ONE 8.2 (2013).

Landow, George P. Hypertext 3.0: Critical Theory and New Media in an Era of Globalization. Johns Hopkins University Press, 2006. 
Liu, Ziming. "Reading behavior in the digital environment: Changes in reading behavior over the past ten years." Journal of Documentation 61.6 (2005): 700-712.

Long, Elizabeth. "Textual Interpretation as Collective Action." Ethnography of Reading. Ed. Jonathan Boyrin. Berkely, Los Angeles, Oxford: University of California Press, 1993. 180-211.

Mangel, Alberto. Istorija čitanja. Novi Sad: Svetovi, 2005.

Mangen, Anne. "Hypertext fiction reading: haptics and immersion." Journal in Research in Reading 31.4 (2008): 409-419.

Mangen, Anne, Bente R. Walgermo and Kolbjørn Brønnick. "Reading linear texts on paper versus computer screen: Effects on reading comprehension." International Journal of Educational Research 58 (2013): 61-68.

Miall, David S. and Teresa Dobson. "Reading Hypertext and the Experience of Literature." Journal of Digital Information [Online] 2.1 (2006).

Price, Leah. "Reading: The State of the Discipline." Book History 7 (2004): 303-320.

Radway, Janice. "Beyond Mary Bailey and Old Maid Librarians: Reimagining Readers and Rethinking Reading." Journal of Education for Library and Information Science 35.4 (1994): 275-296.

Rosenblatt, L. M. The reader, the text, the poem: the transactional theory of the literary work. 2nd. Southern Illinois University Press, 1994.

Sosnoski, James. "Hyper-readers and their Reading Engines." Passions, Politics, and 21st Century Technologies. Ed. G. E. Hawisher and C. L. Selfe. Logan, Utah and Urbana, Illinois: Utah State University Press-NCTE, 1999. 161-177.

Towheed, Shafquat. "Introduction." The History of Reading. Ed. Rosalind Crone and Shafquat Towheed. Vol. 3. Palgrave Macmillan, 2011. 1-12.

Uspenski, Ivana. „Hipertekst kao tekstualnost Interneta i modeli sajbercentričnog čitanja." ART+MEDIA: Časopis za studije umetnosti i medija 1 (2012): 83-92.

Wolf, Maryanne and Mirit Barzillai. "The Importance of Deep Reading." Educational_ Leadership 66.6 (2009): 32-37.

Wolf, Maryanne. "Your Brain on Books: You Are What You Read." Summer 2007. Tufts Magazin. 25 September 2016 <http://emerald.tufts.edu/alumni/magazine/ summer2007/features/read.html>. 


\title{
Violeta Stojmenović \\ National Library, Bor
}

\section{EFFECTS OF DIGITAL TECHNOLOGIES ON READING HABITS FORMATION: THEORY AND A CASE STUDY}

\begin{abstract}
Summary
From the perspective of the history of reading, reading is historically and culturally conditioned interaction of texts, readers-as individuals and as members and representatives of social groups, roles and positions-and media / technology which necessarily affects reading habits, implying possible, desirable and (un)permitted reading practices, as well as the meanings and values a reader discovers in the text. Throughout history, the number of possible reading practices and the ability to manipulate the media, the degree and visibility of interactivity and the variety of reading habits have grown due to the new social and ideological contexts of private, common, public and group reading, and the expansion of new technologies that are changing production methods and types of textual media. The paper will analyse some characteristics of reading digital texts, new possibilities the readers have at their disposal, depending on the format, software or extensions and tools that can be used for reading digital and / or digitized texts and publications. Possible influences that new technologies, new types of texts, the virtual environment and open access to digital facsimiles of previously almost inaccessible sources (manuscripts, for example) might have on reading experiences and habits will be examined, too. On the one hand, we can speak about modifications of practices related to reading manuscripts and print sources (scrolling, marking, annotating or commenting, copying parts of texts for personal use or sharing, connecting readers with common interests for discussions) and the emergence of new modes and tools for reading (full text searchability, programming possible "trajectories" of reading, customisation of interfaces, i.e. layout and components of a text, automatic collation, direct connection of a text with other texts and sources of information, on-line platforms for reading and communication among readers of different profiles and interests, automatic aggregation of certain types of texts, etc.). On the other hand, we can notice heightened sensitivity and research interests in the materiality of manuscripts and print sources, and a reverse impact that reading habits in digital environments have on print texts and publications creation, production and reading. Thus described and analysed possibilities, global trends and critical or theoretical conclusions of the researchers in reading digital texts will be compared with reading practices of Bor secondary school students, examined by a survey, interviews, and tests.
\end{abstract}

Key words: reading, history of reading, reading tools and devices, reading habits, (digital) text, (digital) publication, book 